\section{MICROFINANZAS Y VIVIENDA PARA INMIGRANTES EN LOS EE.UU.: UNA HERRAMIENTA SUSTENTABLE ${ }^{1}$}

Luis Estevez Jimenez ${ }^{2}$

\section{MICROFINANCE AND HOUSING FOR IMMIGRANTS IN THE U.S.A.: A SUSTAINABLE TOOL'1}

Luis Estevez Jimenez ${ }^{2}$

\begin{abstract}
Resumen
La prevención del deterioro barrial mediante la renovación de viviendas se presenta como una oportunidad para promover el desarrollo sustentable. Esta renovación de viviendas, tanto deterioradas como de aquellas construidas progresivamente y con escasos recursos, crea oportunidades sociales y disminuye el consumo de suelo, energía y otros recursos, favoreciendo de esta manera el desarrollo sustentable.

Si bien los Estados Unidos cuentan con años de práctica y teoría en asuntos relacionados con la revitalización y desarrollo barrial, todavía persisten algunos sectores de la población que no cuentan con acceso a oportunidades financieras. Hoy en
\end{abstract}

\begin{abstract}
Preventing neighborhood deterioration through the updating of housing stock is an opportunity for promoting sustainable development. Updating $d$ wellings suffering from not only deterioration but also those created on an incremental basis and with small resources, creates social opportunities, decreases the consumption of land, energy, and other resources, thus promoting sustainable development.

Although the United States has many years of practice and theory in issues related to neighborhood revitalization and development, sectors of population
\end{abstract}


día, estas oportunidades crediticias y de vivienda se encuentran fuera del alcance de importantes grupos de personas, como lo son los inmigrantes. Los países en desarrollo llevan la delantera en lo que se refiere a la creación de estrategias originales para atenuar los problemas relacionados con la vivienda. La microfinanciación para la obtención de viviendas ha evolucionado como una de estas ideas que surgieron para aliviar las condiciones a las que se enfrentan las personas de menos recursos.

El objetivo primordial de este artículo es ofrecer un análisis de las principales características del programa de microfinanciación para la obtención de viviendas, el cual ya ha sido aplicado en algunos de los condados más pobres de Texas, ubicado en la frontera entre los Estados Unidos y México. Este programa nació el año 2000 y ha funcionado con un constante flujo de usuarios. Los resultados de esta investigación establecen las bases para la implementación de programas similares en todos los Estados Unidos.

PALABRAS CLAVE: VIVIENDA INCREMENTAL, MICROFINANCIACIÓN PARA LA OBTENCIÓN DE VIVIENDAS, COLONIAS DE INMIGRANTES EN TEXAS, VIVIENDA ASEQUIBLE.

Fecha de recepción: 30.09.13

Fecha de aceptación: 29.08.14

1 Este artículo analiza datos obtenidos de Sustainability As sessment of Revolving Funds for Financing Affordable Housing, investigación llevada a cabo en la Universidad de Texas A\&M.

2 Estados Unidos. Profesor Asistente, St Cloud State University. Correo electrónico: lestevez@stcloudstate.edu

184 revista invi № 83 / May 2015 / Volume № 30: 183-210 lacking access to financial opportunities still remain. Current financial and housing opportunities are proving to be unaccessable for some important groups such as immigrants. Developing countries have a record of creating original strategies to alleviate problems related to housing. Microfinance for housing has evolved as one of those ideas which have emerged in an attempt to alleviate conditions facing the poor.

The main goal of this article is to present an analysis of the key characteristics of a microfinance program for housing, which has been, implemented in some of the poorest counties in Texas along the U.S.-Mexico border. The program began in 2000 and appears to be working with constant clientele. Findings on this research set the groundwork for the implementation of similar programs across the U.S.

KEYWORDS: INCREMENTAL HOUSING, MICROFINANCE FOR HOUSING, IMMIGRANTS COLONIAS IN TEXAS, AFFORDABLE HOUSING.

Received: 30.09.13

Accepted: 29.08.14

1 This paper analyzes data retrieved from a research project at Texas A\&M University. Title: Sustainability Assessment of Revolving Funds for financing Affordable Housing .

2 Estados Unidos. Assistant Professor St. Cloud State University. Correo electrónico: lestevez@stcloudstate.edu 


\section{Housing improvements and neighborhood development}

The use of housing improvements as an element of upgrading has been a constant in housing policies not only in developing countries but also in developed ones. Countries such as England and the Netherlands have for many years implemented and funded programs related to housing improvements and repair. In England and Wales these policies were established since the 1940s, although it has been recognized that since the 1990s there has been a reduction in aid and grants due to the change of view of the governing bodies regarding the responsibilities of state and private owners along with new alternatives for helping low-income owners with repair and improvements ${ }^{3}$.

In developing countries the rise of upgrading dwellings has reached notoriety in the last few years. The establishment of the Millennium Development Goals at the 8th plenary meeting on September 8, 2000 specified seven specific goals to ensure environmental sustainability and established the target of achieving significant improvement in the quality of lives of at least 100 million slum dwellers

3 Leather, 2000. by 2020. International agencies and governments have committed themselves to these goals; and have been and continue to make changes that they hope will help them achieve these goals ${ }^{4}$.

Although with differing dimensions and characteristics, upgrading has been an integral part of the community development and revitalization efforts in the US. In the last 30 years the responsibility for urban revitalization has shifted from government to community organizations. Most of the current preoccupations in the community development arena is the emphasis on the concept that through improving the physical environments it is possible to build socially better communities ${ }^{5}$.

Different strategies have been used to address urban decline and negative social transformations. Increased homeownership, resettlement and incumbent upgrading are some of those common strategies $^{6}$. For authors such as Baldassare ${ }^{7}$ and $\mathrm{Clay}^{8}$, for example, incumbent upgrading was included in renewal strategies because it was believed that property maintenance and rehabilitation by owners would have benefits such as improvement of housing quality, neighborhood desirability, and resident confidence.

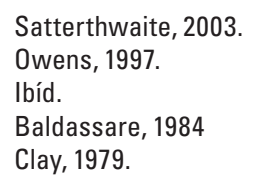


Among the many challenges facing renewal efforts, perhaps the two most important in terms of housing improvements are the diminishment of federal public funding support for these types of strategies $^{9}$ and the ability to create opportunities for the acquisition of credit by low-income owners ${ }^{10}$.

It is in this new context that community development efforts are challenged and where microfinance for housing could be a strategy to support neighborhood development. The strategy of microfinance for housing could overcome some of those challenges.

\section{Microfinance}

\section{ORIGIN AND CURRENT STATUS}

Although Muhammad Yunus (who was awarded the Nobel Peace Prize for 2006) is usually identified as the man who put into action this economic tool, it is important to say that even before him, there were other financial institutions who targeted helping disenfranchised groups; for example, in 1775 the oldest financial institution (a pawnshop) was created in Mexico, under an edict by the Spanish crown to assist people in financial trouble $^{11}$. Although microfinance is an old idea, its

$9 \quad$ Keating, 1996.

11 Armendariz and Morduch, 2005. popularity is as a result of its rapid growth in the last decades. Moreover, in their book "The Economics of Microfinance," Armendariz and Murdoch $^{12}$ identify rotating savings and credit associations (ROSCAs) and credit cooperatives (or credit unions) as precursors to modern microfinance institutions.

The sheer number of microcredit institutions throughout the entire world is incredible. According to Daley-Harris ${ }^{13}$, by December 2004, 3,164 microcredit institutions reported reaching 92,270,289 clients with a current loan. 72 percent of those clients were among the poorest (in the bottom half of those living below their country's poverty line or below US $\$ 1$ a day). In keeping with the tradition of the United Nations of designating every year with a particular name in order to draw attention to major issues, 2005 was named the International Year of Microcredit.

Probably the notoriety of current movement is due to the current conditions facing the world in terms of inequality and poverty, the lack of success of either a planned or market economy, or even because of the failures of foreign aid in making an impact on poverty and inequality. Microfinance is one idea uniquely originating from a bottom up

\footnotetext{
12 Ibíd.

13 Daley-Harris, 2005.
} 
approach, showing that sometimes there is hope in utilizing small ideas to serve the poor.

\section{CRITICISM AND CHALLENGES}

Most of the criticism against the microcredit movement is due to the blown-up expectations created with this tool. Microfinance is not the panacea to all problems facing the poor. It is just an economic tool that can overcome failures of financial markets and reach low income. The main challenge facing microfinance programs is how to prove that this tool is achieving the targets established. More importantly, microfinance programs need to be compared to other options that seek to achieve the same targets (costs and benefits) including other microfinance programs ${ }^{14}$.

Impact evaluations of microfinance programs are facing different methodological challenges. Reliability and unobservable attributes of clients are just the main challenges in impact assessments. For authors such as Armendariz ${ }^{15}$ the use of a randomized approach (using a control group) could be a way to generate confidence in this movement. Last but not least, the questions related to the financial sustainability of microfinance programs and whether the idea of the use of microfinance as a way to give subsidies is valid. Some authors argue

14 Armendariz and Morduch, 2005.

15 Ibíd. that subsidies could free lenders of the challenges of being efficient in order to achieve sustainability. Armendariz cites three concerns regarding subsidies and sustainability: 1) subsidies can limit the scale of operations; 2) a cost-benefit analysis can overstate the benefits of subsidies; and 3) the risk of having donors moving forward to other types of programs.

\section{REPLICATING MICROFINANCE IN THE UNITED STATES}

Microfinance is a concept that has been imported from developing countries to the United States. But, as a result of this adoption many challenges have emerged. For some authors such as $\mathrm{Carr}^{16}$, microfinance is regarded in the US as an innovative policy instrument that promotes social justice. For others such as Schreiner and Murdoch ${ }^{17}$, microfinance in the US complements the ideas about market-based economic approaches and commitment to social justice

It was in the 80's that some microfinance institutions and similar initiatives began to appear in the U.S. Accion International, FINCA, Working Capital, were some of those institutions taking place in the US. As Carr and Tong ${ }^{18}$ indicate, at the beginning of the 1990's there were two important

16 Carr and Tong, 2002.

17 Schreiner and Murdoch, 2002

18 Carr and Tong, 2002. 
events, the emergence of the Association for Enterprise Opportunity in 1991 and the first major legislation established for microenterprises. The main services and characteristics of microfinance in the US are: the incorporation of training and technical assistance and the fact that loan sizes range around the $\$ 35,000^{19}$.

The most common problems that microfinance institutions are facing in the US are low loan volumes, high default rates ${ }^{20}$, not achieving wide outreach and financial sustainability ${ }^{21}$, the requirement of subsidies most of the time ${ }^{22}$, and nonsustainability due to operational inefficiencies ${ }^{23}$. Due to a tradeoff between financial sustainability and outreach it could be unrealistic to expect high levels of financial performance ${ }^{24}$. Servon recognizes that the lack of understanding regarding the differences between US programs and those in developing countries has led to inappropriate expectations $s^{25}$. Servon cites focus on training rather than credit, diversity among programs, the complexity of processes to start a business, and the appropriateness of microfinance as a tool to alleviate

19 Ibíd

20 Carr and Tong, 2002

21 Schreiner and Murdoch, 2002.

22 Von Pischke, 2002.

23 Tang, 2002.

24 Vinelli, 2002.

25 Servon, 2002.

188 revista invi № 83 / Mayo 2015 / Volumen № 30: 185-212 poverty as the main characteristics distinguishing US programs from those in developing countries.

Finally, because most of the microfinance programs in the US are subsidized, a main challenge in the future for microfinance programs is the justification of these types of programs among other programs focused on poverty and development ${ }^{26}$.

\section{MICROFINANCE FOR HOUSING}

In the beginning, microfinance included a small amount of money lent to customers (microcredits) but with the passage of time, different institutions have been adopting other financial services for borrowers (microfinance). Loans for housing are some of those new services offered by some programs.

In many situations housing has been deemed to be of lesser importance, because it was not seen as a productive asset. However, in reality, housing is not only shelter, but also a commodity that offers social security. For example, a house can offer space for income-generating activities such as in a shop or workshop combined with the shelter

26 Schreiner and Murdoch, 2002. 
function or by renting out parts of the land or the house. Shelter also can serve as collateral for obtaining access to financial self-help organizations or credit from, for example, moneylenders, pawnbrokers, relatives, friends and neighbors.

The housing necessity in developing countries, either by new homes or simply housing improvements, is the reason for the constant development of alternatives or practices to solve this situation. For example, in Latin America the most recent practices in progressive housing are: credit, through microfinance programs; land tenure and development; and direct subsidies ${ }^{27}$. Some of these ideas have been developed from studying the livelihood strategies of poor urban households.

In an attempt to define microfinance for housing, Daphnis $^{28}$ suggests two approaches: a product centered definition and a provider-centered definition. These two approaches could be complementary and a point of departure for a further analysis. The product-centered definition requires the use of methodologies of the microfinance approach such as small loans based on a client's capacity to repay, short repayment terms, loan pricing expected to cover the real costs, low use of collateral or substitutes, loans aimed to finance habitat in a incremental basis. If the provider is a microfinance

27 Ferguson and Navarrete, 2003.

28 Daphnis, 2004. institution (MFI), credit could be linked to prior participation in savings or microenterprise loan services. The provider-centered approach is recognized to be more literal than methodological, because it only requires identifying those microfinance organizations offering housing microfinance services.

After analyzing these two approaches as well as the distinguishing characteristics of financial services such as loan amounts, repayment periods and pricing strategies, Daphnis suggests two categories of providers: those that make loans on a stand -alone basis to all eligible clients, including first time clients; and those giving services on a linked basis only to clients who have a prior history with the provider $^{29}$.

In a study done by Daphnis for SIDA, he observed that most institutions recommend that 25 to 35 percent of either net or gross monthly income can be used to pay for the loan. According to this same study, the current practice indicates those repayment periods for housing microfinance loans range from one to ten years, with the vast majority within the one- to five-year range ${ }^{30}$.

In another study done by Merril ${ }^{31}$ it was found that to provide shelter finance to low and moderate income sectors they must fall under the interest of

29 Ibíd.

30 Ibíd.

31 Merril, 2004. 
many types of institutions such as microfinance institutions, cooperatives, government housing programs, commercial banks (including community-based lenders), nongovernmental organizations, and other international actors such as developers and networks.

Another important aspect linked to MFIs is related to the limited capacity to access long-term financing in foreign or local currencies. It is dependent on the complexity and maturity of the financial market in each country. Thus, many MFIs have alternatives (apart from its own funds) for funding such as savings, commercial bank lines of credit, donor and foundation funds, innovative credit enhancements, and group assets mapping. It is common for MFIs to use a combination of funding sources ${ }^{32}$.

Generally speaking, the MFIs housing loan products are focused on home improvements, upgrading, and incremental loans. Sometimes MFIs differentiate the loan product according to the target clients (self-employed, e.g.). Regarding loan terms, most loans for housing improvements generally have terms of three months to two years.

In the same study Merrill shows that programs have different rates, for example, Grameen Bank offers an interest rate of only 8 percent because its loans are

32 Ibíd. highly subsidized. Regarding their clients, MFIs do not have common methodologies. Even within the same country MFIs use different methodologies. Among the different methodological approaches MFIs take into account are: 1) individual loans instead of group lending; 2) different approaches in terms of underwriting and collateral aspects; 3) client history and track record with the same organization; 4) different criteria to asses housing affordability; 5) ownership of the home or land is preferred; 6) technical assistance offered by some organizations; 7) savings accounts and payroll deductions used as method of payment; and 8) pensions and provident funds used as collateral ${ }^{33}$.

In terms of financial viability, MFIs share common issues such as default rate, subsidies, regulation and legal aspects, and scale, capacity and sustainability. The use of a pilot program focused in home improvements is the first step by MFIs to determine costs. For MFIs high default rates do not appear to be a problem (Grameen Bank had ranks of 1 to 7 percent). The use of public funds through MFIs is beginning to be a common practice. Organizations are facing legal and regulatory issues (selecting the appropriate structure remains a problem for micro-lenders). And currently scale, capacity and sustainability are major barriers to effective microfinance for housing ${ }^{34}$.

\section{Ibíd.}

34 lbíd. 
In 2002 the Centre for Urban Development Studies (CUDS) of Harvard published an exhaustive report titled "Housing Microfinance Initiatives. Synthesis and Regional Summaries". The objective of the report was to assess the nature of housing microcredit products that are currently being offered by microfinance organizations ${ }^{35}$.

The CUDS analyzed as case studies those programs that were more important in terms of age and size. The study divided the case studies into three regions: Asia, Latin America, and Sub-Saharan Africa. CUDS identified two types of housing microfinance programs: 1) microcredit to housing finance programs (MCHF); and 2) shelter advocacy to housing finance (SAHF)

According to CUDS, MCHF initially began as microcredit initiatives for small and micro-enterprises. Microfinance institutions found that clients often channel the funds into housing improvements so these institutions decided to include a lending portfolio for housing finance products for construction and housing improvements.

SAHF arose out of a need for the advocacy for the poor in obtaining equitable access to resources (land and shelter as well as adequate infrastructure and services). The main goals of these programs are the empowerment of low-income sectors. These programs also enable the poor to access

35 CUDS, 2000. service land and acquire shelter. SAHF schemes are process-oriented, their primary concern is to empower their constituency and to alleviate the existing inequitable distribution of resources and the underlying structural cause of poverty. Often at the expense of sound financial performance, they pay attention to helping community members build their capacities and develop leadership skills. These schemes are less formal than that of MCHF, and they operate on a smaller scale within limited local boundaries (although have been growing) and their lending products are less specialized.

According to CUDS, the challenges facing the housing microfinance industry are mainly twofold. First, some socio-economic groups are still by and large underserved. Second, although new housing construction and home improvement loan programs are widespread and successful, strategies for financing land acquisition and the provision of infrastructure remain inadequately developed in relation to need.

\section{Replicating microfinance for housing in the United States}

Contrary to the low profile of microfinance for housing in the United States, this movement has reached many people throughout the rest of the 
world and the idea of microfinance has taken different shapes and approaches. Perhaps the number of poor and the needs of many developing countries has been a good laboratory for experimentation. Loans for housing are among the different services offered currently by some microfinance programs. Usually, these loans are focused on housing improvements and not only on new homes.

Some authors recognize crucial differences between the context of housing markets and housing finance in the United States and developing countries. Laws, regulations, programs and the depth of the U.S. financial system allow institutions to move down-market instead of using microfinance institutions. The great U.S. financial depth and stable macroeconomy are the basis for the strong housing finance industry and democratized access to capital (although it is important to recognize some discriminatory practices currently persist ${ }^{36}$.

Because the U.S. financial market is very strong and capable of reaching low income sectors, according to some authors such as Huh and Kolluri ${ }^{37}$, there are at least three segments of the U.S. market with potential to be served from some microfinance exercise: the rehabilitation housing market, the progressive housing market; and the rental housing market. For these authors the potential demand for microfinance for housing could serve the

36 Temkin, 2004.

37 Huh and Kolluri, 2004. demand of those that need short term, affordable home rehabilitation loans, and those not having access to the formal financial sector.

Huh and Kolluri suggest the use of a microfinance pilot program in some of these potential markets, however, this pilot program must demonstrate is ability to be self sustaining, cost-effective and affordable. The authors cite some salient characteristics in order to develop such a pilot program: 1) an examination of the supply and demand conditions; 2) analysis of the cost and profitability; and 3) a well-articulated funding strategy ${ }^{38}$.

Sarkar ${ }^{39}$, who also see the underserved population by the housing finance of the United States as a potential market for hosing microfinance, goes further and proposes the likely profile of housing microfinance in the US: 1) loan amounts in the U.S. are likely to range from $\$ 5,000$ to $\$ 15,000$ contrary to developing countries ( $\$ 300$ to $\$ 5,000$ ); 2 ) the potential of using microfinance loans as bridge financing; 3) and the lending methodology (overall household income taken into account for assessing creditworthiness; use of compulsory savings schemes in underwriting, and technical assistance); and 4) funding housing microfinance (charitable and government funds as credit enhancements as well as a tripartite approach)

\section{Ibíd.}

39 Sarkar, 2004. 
According to Sarkar it is necessary also to identify some areas for a major attention to make microfinance work ${ }^{40}$ : 1) determining pricing for risk and transaction costs; 2) deciding and developing appropriate delivery channels; 3) role of the public sector and philanthropic organizations; 4) building the policy network; and 5) research. According to authors such as Ferguson and Haider ${ }^{41}$, microfinance for housing of low and moderate income households has potential but has not yet been tried in the US. Most of the authors previously cited recognize that among the main obstacles in the US in for implementing microfinance housing the high and inflexible development standards are the most critical ones.

\section{Case study}

By the time some authors ${ }^{42}$ recognized the possibility of microfinance for housing in the U.S., a nonprofit organization (NGO) had a program already in place since 2000 in Texas along the U.S.-Mexico border in what is known as the Colonias.

40 Ibíd.

41 Ferguson and Haider, 2002.

42 Ibíd.

\section{The Colonias context}

In Texas the term colonia refers to an unincorporated settlement along the Texas-Mexico border with poor and insufficient infrastructure. Most colonias are outside city limits or in isolated areas of the county and have very limited property tax base. Housing stock is poor and living conditions are precarious.

The colonia is not a Texas-only phenomenon. The existence of this particular type of settlement has been recognized at the federal level. A colonia is defined as any identifiable community that

1) is located in the states of Arizona, California, New Mexico, or Texas;

2) is within 150 miles of the border between the United States and Mexico (except for metropolitan areas with populations exceeding 1 million);

3 ) is designated as a colonia by the state or county in which it is located; 4) is determined to be a colonia on the basis of objective criteria such as a lack of a potable water supply, inadequate sewage systems, and a shortage of decent, safe and sanitary housing; and 5) was in existence and recognized as a colonia prior to Nov. 28, 1990 3 .

43 Ward, Souza and Giusti, 2004. 
While there are border colonias in Arizona, California, and New Mexico, Texas has a greater number of colonias and more colonia residents. According to a report prepared by The Colonia Initiatives Program of the Office of Texas Secretary of State in 2006, it is estimated that there are approximately 1786 colonias with a total population of 359,825 residents in Texas.

According to 2011 data of the United States Census Bureau ${ }^{44}$, Starr County is one of the poorest counties in the country with a per capita income of US\$12,125 and a median household income of only US $\$ 25,598$. The household income is half the median household income in the state of Texas (US\$50,920) and the nation (US\$52,762). Most of the population in the county resides in the colonias. In the renewal literature the benefits of homeownership are recognized. However, this is not the case in colonias. Based in the same data from the US Census Bureau, homeownership in Starr County $(80.7 \%)$ is higher than in the State of Texas (64.5\%) an in the country (66.1\%). These are truly owners' communities, but with low property values and limited access to financial services, especially for housing.

44 American Community Survey 2007-2011 http://www.census. gov/

194 revista invi № 83 / Mayo 2015 / Volumen № 30: 185-212

\section{The economic context of the state of Texas ${ }^{45}$}

After the housing financial crisis of 2008, according to analysis and indicators of the Federal Reserve Bank of Dallas, the Texas economy continues to expand at a moderate pace. Although the colonias' economic context represents the lowest economic performance not only of the U.S.A. but also of Texas, the following is a brief description of some economic indicators for the state of Texas.

Texas employment has increased with the current employment level at 10.4 million. The Texas unemployment rate was 8.2 percent in November 2010 but still rate remained below the U.S. rate, which was 9.8 percent.

The Texas housing market showed signs of strengthening. Single-family housing permits and housing starts rose in November, although existinghome sales leveled out (Housing starts increased 19.9 percent in November 2010, although the yearover-year level remained basically unchanged. Single-family housing permits rose as well, climbing 5.8 percent from October to November).

Real Texas exports remained well above the previous year's level (Monthly exports rose 3.5 percent in October after ticking up 0.4 percent in

45 Texas Economic Indicators. Federal Reserve Bank of Dallas 2011 http://www.dallasfed.org/index.cfm

ARTICLE: Microfinance and housing for immigrants in the U.S.A.: a sustainable tool / Luis Estevez Jimene 
September. The October level of real exports was 19 percent higher than a year earlier.) The Texas Manufacturing Outlook Survey suggested continued growth in December.

\section{The program and the NGO}

In 1999 a program for loans for housing improvements in the Colonias in Starr County, Texas was developed. The program was created by an NGO called Community Resource Group (CRG) and since its origin was named "Nuestra Casa" (Our House). CRG is a multi-state rural development organization established in 1975 and is involved in rural projects. The goal of the program was to service a basic housing need through a financial program in the absence of any other type of regular financial lenders or governmental agency so as to serve those disenfranchised groups located in the county.

In 1996, at the request if the Texas Attorney General, CRG became the court-appointed receiver charged with clearing titles for the 1,400 low-income families living in the 15 Starr County colonias. Once the strategy of clearing titles was in effect, CRG aimed to improve the housing conditions of the residents. As a result of this last objective, the Nuestra Casa Program was born. CRG had to contract with the Texas Department of to only providing support toward the application for external funding by the CRG.

The program is currently serving most of the population living in the Colonias. Currently, the level of clients in the program remains constant. A key factor that has contributed to the continued existence of this program is that the Nuestra Casa program is a part of other housing services offered by CRG (clearing of titles and new housing). This last aspect confirms those theoretical proposals for combining these types of programs along with others into the same organization in order to make microcredits feasible. The Nuestra Casa program has provided more than 680 loans resulting in more than US\$ 1.7 million in loans. Although the CRG provides other services in addition to the loans for housing improvements, no program funding can be used for any of the other services as it is against the policy of funding agencies and organizations. The benefit lies in having the same staff and offices working together for all programs sharing the overhead costs of the programs.

The Nuestra Casa program could be classified as a stand-alone program. It does not provide any type of construction assistance. Most of the funding for the Nuestra Casa program comes from donors and foundations. As other MFH programs, the program does not differentiate this product according to the clients. 
Loan amounts, terms, and interest rates applied by Nuestra Casa are similar to those used by other MFI programs. The program provides a US $\$ 2,500$ by loan for the first time providers, re-applicants could obtain up to US\$3,500 in subsequent loans. It is important to notice that there is no limit to the number of loans that a client could obtain. A client has to have paid a loan before obtaining another.

The average term for the re-payment is two years. The program does not charge any fee for an application or even late payments. The interest rate the program is using is $9 \%$ which is above the market rates for this type of loan. . Contrary to other MFI programs, Nuestra Casa is not requiring securities such as co-signers, personal guarantees, deposits, savings, previous loans, and guarantor.

Another important aspect is that there are no savings associated with this program. It is solely a home improvement loan program and it does not include technical assistance or supervision of the execution of the improvements. There are no suppliers connected to the loan nor are there any limitations on the type of improvement proposed. The applicant is free to use any contractor, wherever they please, without an evaluation of the contractor's quality. This is all up to the client.

In the early stages of the Nuestra Casa program marketing activities were put into place. However, due to the constraints in the staff's time, it has been discontinued. Other factors affecting the program include the fact that it has perhaps reached the desired scale and therefore has reached its maximum loan capacity. Table 1 shows with detail the characteristics of the program.

In regards to the client valuation, an affordability analysis is done to determine the debt-income ratio of applicants. The program uses a maximum debt-income ratio of $40 \%$ per family. The program does not consider any type of technical analysis or assistance perhaps because most of the improvements are not related to structural aspects of the housing and because of the characteristics of the improvements. The program only requires an estimated raw budget of the housing improvement from the applicants. This provides more flexibility for the borrower to implement changes in the improvement.

It is important to point out how the Nuestra Casa Program compares to other similar organizations in other geographical areas. Table 2 shows a comparison between the Nuestra Casa Program and other similar programs located in other countries. In general terms the conditions of the program for obtaining loans are pretty similar to those of other countries. Finally, it is worth mentioning that the financial requirements of the Nuestra Casa Program are completely different from those of mainstream banking, or more specifically, it does not have the same requirements that regular commercial lenders have. Credit history and personal 
TABLE 1. SUMMARY OF CHARACTERISTICS

\begin{tabular}{ll} 
Focus: & Home improvements \\
Funds & Several external donors \\
\hline Service provided & Microcredit for housing improvements \\
& No technical assistance, only supervision of improvements \\
\hline Eligibility requirements and loan term & Individual loans \\
conditions: & No saving schemes \\
& No co-signatures liability for individual default \\
& Legal home tenancy required \\
& Interest rate of 9\% \\
& Average term: two years \\
& Maximum amount of loan: US\$2,500 \\
& Other specific requirements: \\
& Budgets of materials and labor \\
& Social security \\
& Prove of income (income tax, checks of job, government stamps) \\
& When no social security any other type of ID \\
& No legal residence status required \\
\hline Typical loan: & Maximum amount: $\$ 2,500$ (first loan), 24 month terms, amount by month: \\
& 115.00 and a last payment of 95.00 \\
\hline Criteria for financial eligibility: & The expenses of the client should not be above 40\% of his/ her income \\
& Credit history \\
\hline Time average of approval of loan & 2 to 3 weeks \\
\hline Process regarding non-payment & Phone call, visit, layer letter and finally no legal demand (loss of loan) \\
& No report of the case to any authority or entity \\
\hline Client: & Anyone capable affording the loan and payments (no eligibility limitations \\
& regarding this aspect) \\
\hline
\end{tabular}

Source: Giusti and Estevez, 2006 
credit reports (which are the typical requirements for obtaining a conventional loan) are the main differences. These are also the main constraints for low-income people to have access to a conventional loan.

\section{Data and methodology}

The data used by this analysis come from a data base created by an impact assessment of the Nuestra Casa Program ${ }^{46}$. In order to obtain all this data, the research team relied on both quantitative and qualitative tools such as direct surveys, personal interviews, focus groups and data collected directly from the program. A key component of this impact assessment was the use of a control and treatment group in order to have a more accurate evaluation.

CRG provided a database of all loan applications from registered clients since 2000. This database contained information of the 688 loans including name, address, expenditures, income, loan payments, and rates of default of all CRG clients. Because some clients received up to four loans, the database had to be revised to obtain the unduplicated number of clients, which was the point of analysis. The result was 609 clients who represent the total amount of participants the analysis.

46 Giusti and Estevez, 2006.
The CRG database did not contain many demographics for each loan recipient. To compensate for this limitation and to gather more detailed information on borrowers, the research collected data from a questionnaire survey administered to a sample of 236 clients drawn from this database. To choose a representative sample size and minimize selection bias, a random sampling technique was used. In terms of sample size, the study predefined as acceptable a 5\% error margin, a 95\% confidence level and a 50\% response distribution. Based on these figures, it was estimated that a sample size of 236 respondents would optimize the results.

The CRG staff in Las Lomas provided maps of the houses for the selected respondents. While the objective was to complete all 236 surveys, the study was able to secure only 173 surveys (73\% of the optimal size sample). The researchers also conducted a set of personal in-depth interviews with selected loan recipients. The interviews were then transcribed and classified through layers of themes.

The data available from this program's assessment is rich in information (both cross-sectional and longitudinal data is available). It could allow a more in depth empirical analysis, but for the purpose of this article, the description of the program and analysis of selected variables are the main purpose. It is important to note that to show causation was not 
TABLE 2. EXAMPLES OF STAND-ALONE HOUSING MICROFINANCE PRODUCTS

\begin{tabular}{|c|c|c|c|c|c|c|c|}
\hline Organization & $\begin{array}{l}\text { Average } \\
\text { Loan size }\end{array}$ & $\begin{array}{l}\text { Maximum } \\
\text { repayment period }\end{array}$ & $\begin{array}{l}\text { Security } \\
\text { Collateral }\end{array}$ & $\begin{array}{l}\text { Required time } \\
\text { with program }\end{array}$ & $\begin{array}{l}\text { Savings } \\
\text { required }\end{array}$ & $\begin{array}{l}\text { Solution } \\
\text { type }\end{array}$ & Location \\
\hline ADEMI & US\$4,000 & 36 mos. & $\begin{array}{l}\text { Loan } \\
\text { collateralized }\end{array}$ & None & No & Variable & $\begin{array}{l}\text { Dominican } \\
\text { Republic }\end{array}$ \\
\hline FUNHAVI & US $\$ 1,500$ & 20 mos. & 2 cosigners & None & No & Variable & Mexico \\
\hline CHF/ Gaza & US $\$ 4,800$ & $36 \mathrm{mos}$. & 2 cosigners & None & No & Variable & Gaza/West Bank \\
\hline $\begin{array}{l}\text { Nuestra Casa } \\
\text { Program }\end{array}$ & US $\$ 2,500$ & 24 mos. & No cosigners & None & No & Variable & U.S.A. \\
\hline
\end{tabular}

Sources: Daphnis, 2004; Giusti and Estevez, 2006

considered as part of the analysis in this article, therefore no specific techniques were implemented for such purpose. The goal was to make this case study known as being unique in the U.S.A. and its possible contribution to other geographical contexts for purposes of application or further inquiry.

As in the case of causality, it is important to clarify that in methodological terms, the evaluations of these types of programs always bring into consideration methodological concerns, especially induce selectivity biases because of the nature of program participation (endogeneity). As is common in this type of program, the data has not been collected within an experimental context.

ARTíCULO: Microfinanzas y vivienda para inmigrantes en los E.E.U.U.: una herramienta sustentable / Luis Estevez Jimenez
Self-selection and purposive placement are the predominant sources of bias in program evalua$\operatorname{tion}^{47}$. Although it was not the purpose of this article, it is important to mention that the database provides information that could allow the use of instrumental variables to deal with this type of bias through the implementation of some statistical methods well recognized in the evaluation literature ${ }^{48}$. For instance, geographic and household data offer suitable control variables to estimate program impacts at the individual level in a valid way controlling for induced bias described before. Propensity score matching has also been proved to offer a methodological approach to solving self-selectivity bias ${ }^{49}$.

$47 \quad$ Kling et al, 2008

48 See Mofitt 1991 as an example.

49 See, for example, Black and Smith, 2004 and Morgan and Harding, 2006. 


\section{Analysis}

Income, type of home improvements, loans as a main source of income for improvement, and reapplication (multiple loans) were the key variables used to elaborate the analysis presented in this article.

\section{Income}

According to the Nuestra Casa data, the median household income of borrowers was between US\$9,864 and US\$15,768 (in 2011 dollars ${ }^{50}$ ). These numbers are lower than the county level but a little on the upper edge of Las Lomas.

Regarding poverty levels, in 2011, the family poverty threshold was US\$17,029. According to the numbers presented above in terms of income, and the average size of the family in the colonias ${ }^{51}$, it was estimated that at least $70 \%$ of families that received the Nuestra Casa loan were below poverty level.

Another way to evaluate the level of poverty of borrowers receiving loans was to compare the level of income of those receiving the loans and those

50 The CPI is used to deflate current into constant dollars. It uses the average Consumer Price Index for each calendar year.

51 According to the survey the median number of persons per household found is four. who did not. Figure 1 shows the comparison in income between the control (those not receiving the loans) and experimental group (those receiving the loans) used by Giusti in her impact assessment ${ }^{52}$. Interestingly, the experimental group shows a slightly lower level of income compared to the control group. This result shows that the program is reaching those families with lower incomes living in the colonias.

To validate this conclusion, the client's information coming directly from the program was also analyzed. According to this information it was estimated that $60 \%$ of the families receiving the loans were below the poverty line, just 10 points of difference from the percents obtained from the surveys applied by Giusti ${ }^{53}$.

Regarding income, another question was explored: how is this level of income distributed among the borrowers taking in account the age and gender? In order to obtain a more detail ed perspective of the outreach of the program this was an important question. A higher concentration of clients was found in two age groups: 1) 30-39 years of age and 2) older than 50 years of age.

These two distinctive age groups represent two very different stages in life. In the first case, from

52 Giusti and Estevez, 2006.

53 Ibíd. 
FIGURE 1 . MONTHLY INCOME PER HOUSEHOLD IN 2011 (DOLLARS).

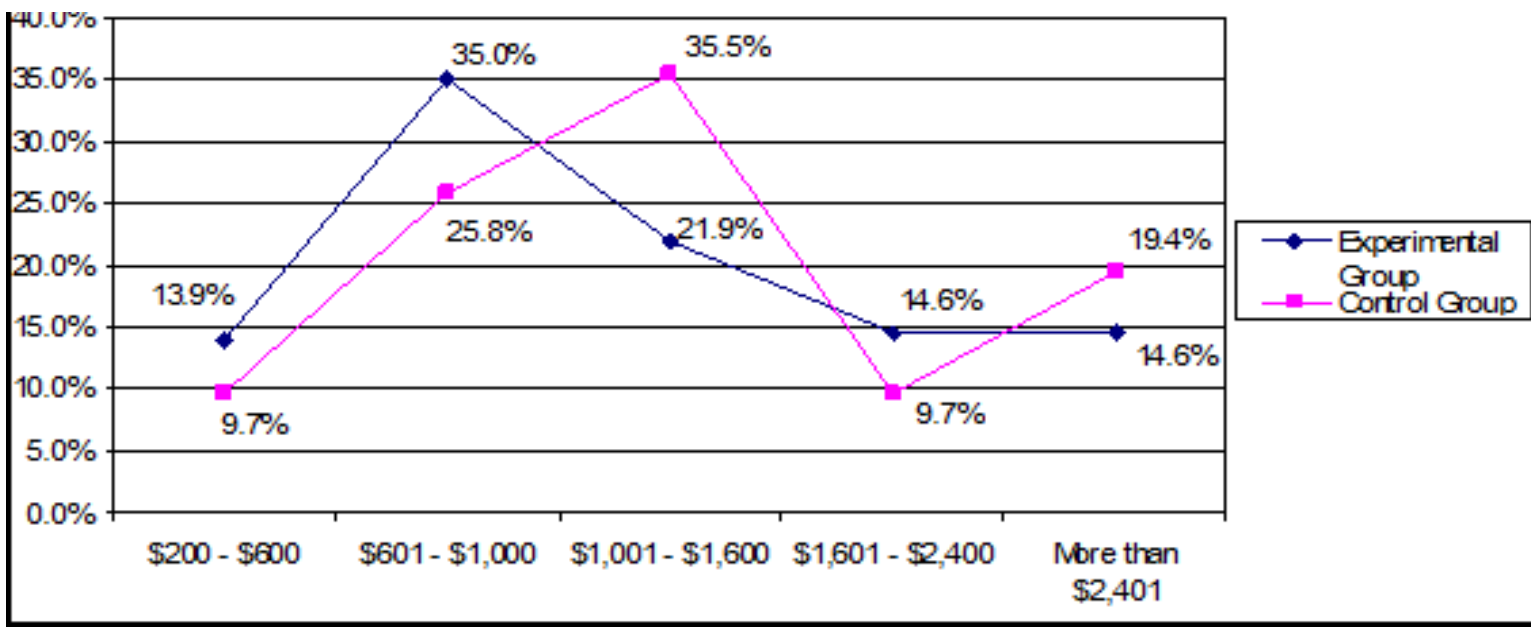

Source: elaborated by the author with information from Giusti and Estevez, 2006.

30-39 years is when the family is consolidating, are in most need of a house, and are ready to afford payments. The other distinctive group of more than 50 years of age may reflect the fact that this group has less obligations thus may be more able to manage a loans.

In order to establish a relationship between level of income and age, a cross-tabulation was done. Tables 3 and 4 show the results of this statistical process. The results depict that for males, $78 \%$ of the older group (more than 50 ) is located in the bottom income group, receiving less than US $\$ 821$ per month, and $30.4 \%$ receiving less than $\$ 492$ per month.

ARTíCULO: Microfinanzas y vivienda para inmigrantes en los E.E.U.U.: una herramienta sustentable / Luis Estevez Jimenez
Equally, 53\% of respondents within the age group of 30 - 39 years of age have an income of less than US $\$ 821$ per month. The other two age groups (2129 , and $40-50$ ) only a $28.6 \%$ and 27.3 respectively is located in the same low income group.

For females it was observed that in the group of more than 50 years of age, $72 \%$ were located in the lowest income quintile. However, dissimilar from the male case age group of 30- 39 years of age, the percentage of population in the lowest quintile is just $24 \%$. Women are more evenly distributed among the lowest income levels in almost all age groups. 
The tables above show that $54 \%$ of males and $46 \%$ of females reported an income of less than US\$9,582 a year. Further, $12.5 \%$ of males and $13.7 \%$ of females reported an annual income of less than US\$5,904.

The analysis done by using level of income and the distribution among the different age groups and gender shows that the Nuestra Casa program is reaching important disenfranchised groups not only at the county and state level but also at the national level when compared.

\section{Home improvements}

The variety of improvements that have been done with this apparently limited amount of money received by homeowners is extraordinary and it is based upon local residents getting most out of their money. Further, a considerable proportion of clients have requested more than one loan and, in these cases, the improvements are more evident.

Choosing this variable in this analysis was important because most of the improvements made by borrowers were more than just small improvements. Most of the improvements could have, in the short term, an important impact in the living conditions of borrowers.

Table 5 shows only those types of improvements done with the first loan. The highest percentage of improvements are in air conditioning (15\%), followed by floor work (12\%), roof (11.5\%), fence (8\%), cabinets (7\%), wall (5\%) and annex with $4 \%$.

It is very important to look at the importance of these improvements in terms of the quality of life of the households. We can see that air conditioning is a very important one as most of these houses (as per personal interviews) did not have this type of equipment before. In the middle of the summer, with few trees around and no heat insulation, the benefits of having a comfortable climate inside of houses has a major impact on the quality of life of the family. It is relevant to point out one of the side benefits of this improvement as it could mean an immediate substantial increase in electricity consumption and therefore in utility payments.

In the case of floor improvements, some borrowers did not have an existing floor in place, or they had floors made from rough concrete or just dirt. As most of the houses lacked a roof made from durable and secure materials, most of these types of improvements were to build a roof with durable materials such as concrete. It is important to point out that when the improvement referred to walls, this did not mean just to add a division into the house. In many cases these borrowers were adding a second floor to the house.

Many borrowers were able to make important improvements with a small loan. Two reasons which enabled borrowers to make such important 
TABLE 3. CROSS-TABULATION AGE-INCOME MALE

\begin{tabular}{llllllll} 
AGE MALE & \multicolumn{6}{c}{ TOTAL INCOME PER HOUSEHOLD PER MONTH IN 2011 (constant dollars) } \\
& & $\$ 164-492$ & $\$ 493-821$ & $\$ 822-1,314$ & $\$ 1,315-1,970$ & More than 1,971 & Total \\
\hline $21-29$ & Count & 0 & 2 & 2 & 3 & 0 & 7 \\
\hline & $\%$ & $.0 \%$ & $28.6 \%$ & $28.6 \%$ & $42.9 \%$ & $.0 \%$ & $100.0 \%$ \\
\hline $30-39$ & Count & 0 & 8 & 3 & 2 & 2 & 15 \\
\hline & $\%$ & $.0 \%$ & $53.3 \%$ & $20.0 \%$ & $13.3 \%$ & $13.3 \%$ & $100.0 \%$ \\
\hline $40-50$ & Count & 0 & 3 & 6 & 0 & 2 & 11 \\
\hline & $\%$ & $.0 \%$ & $27.3 \%$ & $54.5 \%$ & $.0 \%$ & $18.2 \%$ & $100.0 \%$ \\
\hline More than 50 Count & 7 & 11 & 2 & 3 & 0 & 23 \\
\hline & $\%$ & $30.4 \%$ & $47.8 \%$ & $8.7 \%$ & $13.0 \%$ & $.0 \%$ & $100.0 \%$ \\
\hline Total & Count & 7 & 24 & 13 & 8 & 4 & 56 \\
\hline$\%$ & & $12.5 \%$ & $42.9 \%$ & $23.2 \%$ & $14.3 \%$ & $7.1 \%$ & $100.0 \%$ \\
\hline
\end{tabular}

Source: elaborated by the author with information from Giusti and Estevez, 2006.

TABLE 4. CROSS-TABULATION AGE-INCOME FEMALE

\begin{tabular}{llllllll} 
AGE FEMALE & \multicolumn{7}{l}{1999 TOTAL INCOME PER HOUSEHOLD PER MONTH (in 1999 dollars) } \\
& & $\$ 164-492$ & $\$ 493-821$ & $\$ 822-1,314$ & $\$ 1,315-1,970$ & More than 1,971 & Total \\
\hline $21-29$ & Count & 0 & 4 & 2 & 2 & 5 & 13 \\
\hline & $\%$ & $.0 \%$ & $30.8 \%$ & $15.4 \%$ & $15.4 \%$ & $38.5 \%$ & $100.0 \%$ \\
\hline $30-39$ & Count & 2 & 6 & 6 & 8 & 11 & 33 \\
\hline & $\%$ & $6.1 \%$ & $18.2 \%$ & $18.2 \%$ & $24.2 \%$ & $33.3 \%$ & $100.0 \%$ \\
\hline $40-50$ & Count & 2 & 7 & 6 & 3 & 2 & 20 \\
\hline & $\%$ & $10.0 \%$ & $35.0 \%$ & $30.0 \%$ & $15.0 \%$ & $10.0 \%$ & $100.0 \%$ \\
\hline More than 50 Count & 10 & 16 & 7 & 2 & 1 & 36 \\
\hline & $\%$ & $27.8 \%$ & $44.4 \%$ & $19.4 \%$ & $5.6 \%$ & $2.8 \%$ & $100.0 \%$ \\
\hline Total & Count & 14 & 33 & 21 & 15 & 19 & 102 \\
\hline$\%$ & & $13.7 \%$ & $32.4 \%$ & $20.6 \%$ & $14.7 \%$ & $18.6 \%$ & $100.0 \%$ \\
\hline
\end{tabular}

Source: elaborated by the author with information from Giusti and Estevez, 2006. 
improvements: first, borrowers applied and received more than one loan and second, most of the borrowers stated that they were doing the improvements by themselves or with the support of other relatives who were not receiving payment for helping.

In many cases it was evident that borrowers were incrementally building instead of just making housing improvements. What is interesting is the similarity of this process to those observed traditionally in developing countries.

\section{Loan as main source of income for improvement}

When taking into account the magnitude of some of the improvements made by the borrowers, it was initially thought that most of the borrowers were using other sources of funding in order to increase the amount of money available. Most people tend to complement a main loan with other sources such as savings, cash through credit cards, among others sources. Surprisingly, $73 \%$ of borrowers declared not having other sources of funding to complement the loan received.

The next highest percent (15.22\%) reported having a maximum amount of money similar to that of the amount received by the Nuestra Casa program. According to this number it is clear that borrowers were using other approaches in order to maximize the impact of the loan in their housing improvements.

The resulting question after this observation was why borrowers did not have other sources of funding such as other financial sources. Obviously most of the borrowers declared they did not have access to other financial services. Figure 2 shows that the most cited reason for not having access to other financial sources (41.3\%) was the high cost of lending. Not having credit history and enough income were the following reasons representing $43.5 \%$ of those surveyed.

It is obvious that most of the borrowers of the program are not only those with the lowest income levels of the county but also are those with serous limitations in regards to having access to regular commercial lenders.

\section{Re-application}

It is important to understand that much of the reason for the magnitude of the improvements was the use of more than one loan by borrowers making the number of loans received the another key variable analyzed. Part of the original design of the Nuestra Casa program was to allow borrowers to apply for consecutive loans as they were paid off. This was an interesting incentive in order to have good clients. Following loans were designed 
TABLE 5. TYPES OF IMPROVEMENTS

\begin{tabular}{ll} 
Improvement & Percent \\
\hline Air conditioning & 15.2 \\
\hline Floor & 12.3 \\
\hline Roof & 11.6 \\
\hline Fence & 8.0 \\
\hline Cabinets & 7.2 \\
\hline Wall & 5.1 \\
\hline Annex & 4.3 \\
\hline Other & 36.3 \\
\hline Total & 100.0
\end{tabular}

Source: elaborated by the author with information from Giusti and Estevez, 2006

for an amount of money higher than the first one $(\$ 2,500.00$ and $\$ 3,500.00)$.

Re-application is an effective part of micro-credit strategies because of the small amount of the loan and in order to have a more profound effect on the borrowers. According to the information from the data base of the Nuestra Casa program (see figure 3) $59 \%$ of borrowers have received a loan only once $(\$ 2,500.00), 28.2 \%$ have received a loan twice $(\$ 6,000.00), 10 \%$ three times $(\$ 9,000.00)$ and 5 borrowers received four loans $(2.8 \%, \$ 15,000.00)$.
FIGURE 2. REASONS NOT TO HAVE ACCESS TO OTHER LOANS

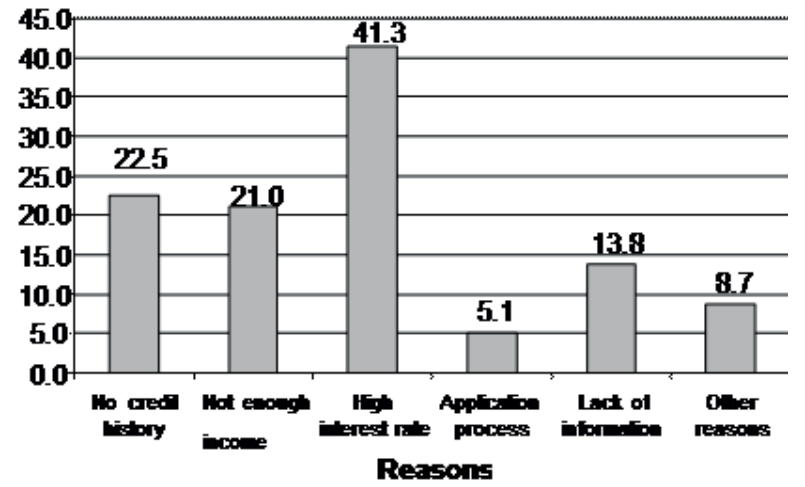

Source: elaborated by the author with information from Giusti and Estevez, 2006.

This strategy is supported by the policy that allows borrowers to apply for a new loan after paying the first loan on time during the first year. The remaining debt is carried out by the new loan in similar financial terms.

By receiving more than one loan meant that borrowers had access in most cases to an amount of US\$6,000.00. This aspect coupled with the capacity of borrowers to make some improvements by themselves explains in some way the magnitude of those improvements. 
FIGURE 3. TIMES BORROWERS HAVE OBTAINED A NUESTRA CASA LOAN

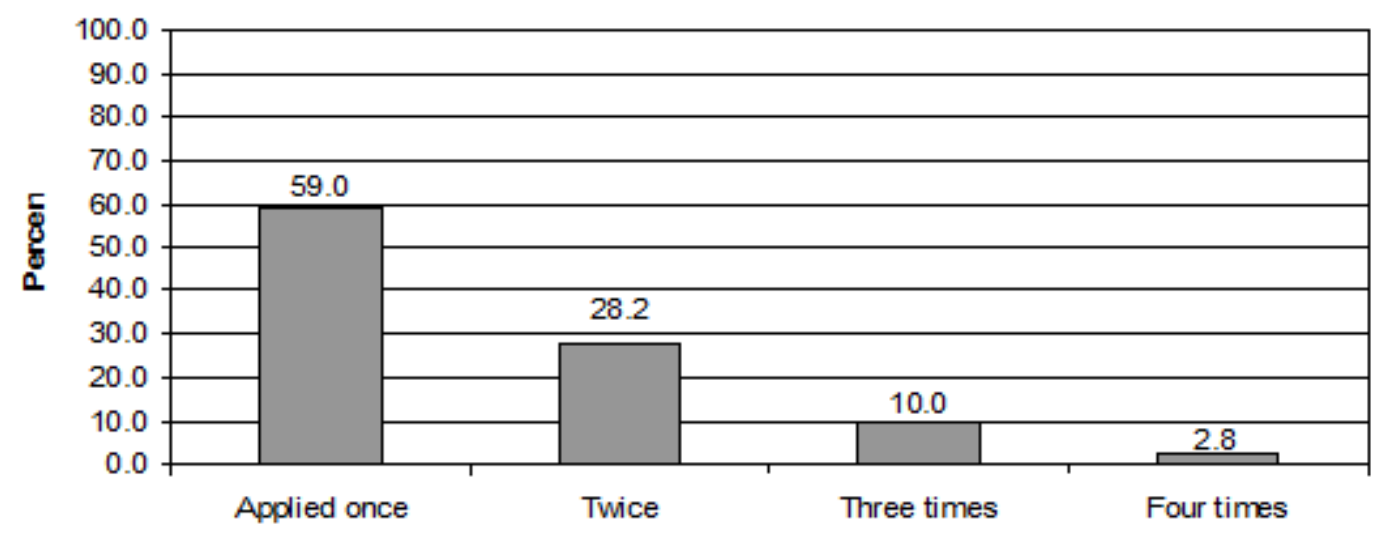

Source: elaborated by the author with information from Giusti and Estevez, 2006.

On the other hand, the aspect of having borrowers receiving a loan more than once raises the question that if borrowers are allowed to re-apply for a second loan does it limit the access to loans by first applicants. Unfortunately, the data available did not allow for significant information to answer this question.

\section{Conclusions}

The conclusions about the outreach of the Nuestra Casa Program based on this analysis could be summarized by the following:
- The program seems to be reaching those low and very low income sectors not only in the Starr County but also when compared to other parts of the U.S.

- In many cases borrowers were using the loan money for incremental housing instead of just housing improvements.

- By not requiring collateral, Nuestra Casa makes this program extraordinarily flexible.

The Nuestra Casa microfinance for housing program is reaching those low and very low-income 
households in the nation. It is important to point out that most of the residents in this area and those receiving the loans are immigrants or foreign born citizens. This sector of the population is unable to have access to the regular financial mainstream; therefore, approaches like that of microfinance for housing could be used in order to reach these disenfranchised groups.

Most of the borrowers attempted to maximize the benefits of the amount of money received. In most cases it was observed that there was a real process of incremental housing. Having the opportunity of receiving more than one loan played an important role in this aspect. Not having other funding sources to increase the amount of money available demonstrates the lack resources available in order to make more important improvements in resident's living conditions.

This analysis raises important questions for future research. Why is this program so flexible in terms of not requiring any type of collateral? A first hypothesis could be that most of these residents are aware of the importance of having a good credit history in the U.S. so they are conscious about the future implications of not having a good credit history.

Due to the magnitude of the improvements, other questions are: 1) what impact will such improvements have on borrowers in terms of health, income and education? 2) is there some impact at

ARTíCULO: Microfinanzas y vivienda para inmigrantes en los E.E.U.U.: una herramienta sustentable / Luis Estevez Jimenez the neighborhood level once a certain number of houses have been improved? Further research will require a set of indicators for determining the level and direction of change in neighborhoods over time: property values, household income, poverty rates and population size, among others.

It is important to recognize some potential policy implications with these types of microfinancing for housing programs. The possibility of being a way to re-direct subsidies to those in need of support is one. The possibility of using these types of approaches as a tool to alleviate poverty is another. Finally, the feasibility of using this approach as a strategy to support sustainable neighborhood development becomes a possibility.

\section{Bibliography}

ARMENDARIZ DE AGHION, Beatriz and MORDUCH, Jonathan. The economics of microfinance. Cambridge, MA, MIT Press. 2005.

BALDASSARE, Mark. Evidence for neighborhood revitalization: Manhattan. In: PALEN Bruce, J. John. Gentrification, displacement and neighborhood revitalization. Albany, NY, State University of New York Press.1984. p. 90-102.

BLACK, Dan A. and SMITH, Jeffrey A. How robust is the evidence on the effects of college quality? Evidence from matching. [Online] Journal of Econometrics. 121(1-2): 99-124, 2004. ISSN 0304-4076. 
Available in: http://dx.doi.org/10.1016/j. jeconom.2003.10.006.

CARR, James H., ed. and TONG, Zhong Yi, ed. Replicating microfinance in the United States. Washington, D.C.: Woodrow Wilson Center Press. 2002.

CLAY, Phillip L. Neighborhood renewal: middle-class resettlement and incumbent upgrading in American neighborhoods. Lexington, MA: Lexington Books. 1979

CUDS The Center for Urban Development Studies. Housing microfinance initiatives: synthesis and regional summary: Asia, Latin America, and Sub-Saharan Africa with selected case studies. Bethesda, Maryland, The Center for Urban Development Studies, Harvard University Graduate School of Design, Development Alternatives Inc. (DAI). 2000.

DALEY-HARRIS, Sam. The state of the microcredit summit campaign report 2005. Washington, DC 20001 USA: Microcredit Summit Campaign. 2005.

DAPHNIS, Franck. Elements of product design for housing microfinance. In: FERGUSON, Bruce and DAPHNIS, Franck. Housing microfinance: a guide to practice. Bloomfield, CT, Kumarian Press. 2004.

----- Housing microfinance: toward a definition. In: FERGUSON, Bruce and DAPHNIS, Franck. Housing microfinance: a guide to practice. Bloomfield, CT, Kumarian Press. 2004. p. 1-14.
FERGUSON, Bruce and HAIDER, Elinor R. Microfinance for progresive housing: can techniques from developing countries be adapted in the United States? In: CARR, James H., ed. and TONG, Zhong Yi, ed. Replicating microfinance in the United States. Washington, D.C., Woodrow Wilson Center Press. 2002. p. 299-330.

FERGUSON, Bruce and NAVARRETE, Jesus. New approaches to progressive housing in Latin America: A key to habitat programs and policy. [Online]. Habitat International. 27(2): 309-323, 2003. ISSN 0197-3975. Available in: http://dx.doi. org/10.1016/s0197-3975(03)00013-4.

GIUSTI, Cecilia and ESTEVEZ, Luis. Nuestra casa home improvement loan program assessment. College Station, TX: Texas A\&M University. 2006.

HUH, Kil and KOLLURI, Lopa P. The market for housing microfinance in the United States. In: FERGUSON, Bruce and DAPHNIS, Franck. Housing microfinance: a guide to practice. Bloomfield, CT, Kumarian Press. 2004.

KEATING, W. Dennis; KRUMHOLZ, Norman and STAR, Philip. Revitalizing urban neighborhoods. Lawrence, KS, University Press of Kansas. 1996.

KLING, Jeffrey R.; KESSLER, Ronald C.; LUDWIG, Jens; SANBONMATSU, Lisa; LIEBMAN, Jeffrey B.; DUNCAN, Greg J. and KATZ, Lawrence. What can we learn about neighborhood effects from the moving to opportunity experiment? [Online]. American Journal of Sociology. 114(1): 14488, 2008. ISSN 1537-5390. Available in: http:// dx.doi.org/10.1086/588741. 
LEATHER, Philip. Grants to home-owners: A policy in search of objectives. [Online]. Housing Studies. 15(2): 149-168. 2000. ISSN 1466-1810. Available in: http://dx.doi.org/10.1080/02673030082333.

MERRILL, Sally and ESCOBAR, Alejandro. Housing microfinance: the state of the practice. In: FERGUSON, Bruce and DAPHNIS, Franck. Housing microfinance: a guide to practice. Bloomfield, CT, Kumarian Press. 2004.

MORGAN, Stephen L. and HARDING, David J. Matching estimators of causal effects: prospects and pitfalls in theory and practice. [Online]. Sociological Methods and Research. 35(3), 3-60, 2006. ISSN 1552-8294. Available in: http://dx.doi. org/10.1177/0049124106289164.

MOFITT, Robert. Program evaluation with nonexperimental data. [Online]. Evaluation Review. 15(3): 291-314, 1991. ISSN 1552-3926. Available in: http://dx.doi.org/10.1177/0193841x9101500301.

OWENS, Michael Leo. Renewal in a working-class black neighborhood. [Online]. Journal of Urban Affairs. 19(2): 183-205, 1997. ISSN 1467-9906. Available in: $\quad$ http://dx.doi.org/10.1111/j.1467-9906.1997. tb00403.x.

SARKAR, Sohini and KCKEE, Katharine W. The future of housing microfinance in the United States. In: FERGUSON, Bruce and DAPHNIS, Franck. Housing microfinance: a guide to practice. Bloomfield, CT, Kumarian Press. 2004.

SATTERTHWAITE, David. The Millennium Development Goals and urban poverty reduction: great

ARTíCULO: Microfinanzas y vivienda para inmigrantes en los E.E.U.U.: una herramienta sustentable / Luis Estevez Jimenez expectations and nonsense statistics. Environment and Urbanization. 15(2): 181-190, 2003. ISSN 1746-0301. Available in: http://dx.doi. org/10.1177/095624780301500208.

SCHREINER, Mark and MORDUCH, Jonathan. Opportunities and challenges for microfinance in the United States. In: CARR, James H., ed. and TONG, Zhong Yi, ed. Replicating microfinance in the United States. Washington, D.C., Woodrow Wilson Center Press. 2002. p. 19-64.

SERVON, Lisa J. Fulfilling the potential of the U.S. microenterprise strategy. In: CARR, James H., ed. and TONG, Zhong Yi, ed. Replicating microfinance in the United States. Washington, D.C., Woodrow Wilson Center Press. 2002. p. 169-190.

TANG, Shui Yan; BHATT, Nitin and PAINTER, Gary. Microcredit programs in the United States: the challenges of outreach and sustainability. In: CARR, James H., ed. and TONG, Zhong Yi, ed. Replicating microfinance in the United States. Washington, D.C., Woodrow Wilson Center Press. 2002. p. 191-222.

TEMKIN, K. and FERGUSON, Bruce. The context for housing microfinance in the United States. In: FERGUSON, Bruce and DAPHNIS, Franck. Housing microfinance: a guide to practice. Bloomfield, CT, Kumarian Press. 2004.

VINELLI, Andres. (2002). Financial Sustainability in the U.S. Microfinance Organizations: Lessons from Developing Countries. In: CARR, James H., ed. and TONG, Zhong Yi, ed. Replicating 
microfinance in the United States. Washington, D.C., Woodrow Wilson Center Press. 2002. p. 137-168.

VON PISCHKE, J.D. Microfinance in Developing Countries. In: CARR, James H., ed. and TONG, Zhong Yi, ed. Replicating microfinance in the United States. Washington, D.C., Woodrow Wilson Center Press. 2002. p. 65-96.

WARD, Peter M.; SOUZA, Flavio de and GIUSTI, Cecilia. 'Colonia' land and housing market performance and the impact of lot title regularisation in Texas. Urban Studies. 41(13): 2621-2646, 2004. ISSN 1360-063X. Available in: http://dx.doi.org/1 0.1080/0042098042000294592. 